\title{
E-commerce in China amid COVID-19 pandemic restrictions
}

\author{
Svetlana Yu. Revinova $\otimes$, Ekaterina A. Ivashchenko \\ Peoples' Friendship University of Russia (RUDN University), \\ 6 Miklukho-Maklaya St, Moscow, 117198, Russian Federation \\ 凶revinova-syu@rudn.ru
}

\begin{abstract}
The COVID-19 pandemic has had a significant impact on all areas of life, including e-commerce. Most experts note a positive effect on e-commerce. E-commerce volume has grown all over the world. At the same time, structural changes took place; consumers changed their behavior and priorities. The purpose of the research is to study the role of e-commerce in China during the period of pandemic restrictions and analyze the statistical and structural changes in e-commerce during the epidemic. Quantitative and qualitative analysis is provided and the prospects for e-commerce in China are identified. When conducting the study, the methods of statistical and comparative analysis were used. The data sources were materials from the National Bureau of Statistics of China and other open sources. To determine the prospects for e-commerce, a model with an additive component was build. The data was deseasonalized, several trend variants were calculated, and the most suitable trend was selected, best approximating the sales data. The analysis showed that China has seen growth in e-commerce during the pandemic, but not as strong as expected. It is noted that before the pandemic, e-commerce grew at a reasonably rapid pace, and the pandemic only accelerated it a little. During the pandemic, those companies that had not previously used the Internet were forced to switch to new sales forms. The epidemic also prompted people to try many new products and services and then develop new consumer habits, which in the long term will continue the growth of e-commerce.
\end{abstract}

Keywords: e-commerce, e-retail, COVID-19, pandemic restriction, China

Acknowledgements. This paper has been supported by the RUDN University Strategic Academic Leadership Program.

Article history: received June 10, 2021; revised July 1, 2021; accepted August 15, 2021.

For citation: Revinova, S.Yu., \& Ivashchenko, E.A. (2021). E-commerce in China amid COVID-19 pandemic restrictions. RUDN Journal of Economics, 29(4), 699-715. http://dx.doi.org/10.22363/2313-2329-2021-29-4-699-715 


\title{
Электронная коммерция в КНР в условиях пандемических ограничений COVID-19
}

\author{
С.Ю. Ревинова $\mathbb{D}^{\otimes}$, Е.А. Иващенко \\ Российский университет дружбы народов, \\ Российская Федерачия, 117198, Москва, ул. Миклухо-Маклая, д. 6 \\ $\bigotimes$ revinova-syu@rudn.ru
}

\begin{abstract}
Аннотация. Пандемия COVID-19 оказала большое влияние на все сферы жизни, в том числе на электронную коммерцию. Большинство экспертов отмечают положительный эффект, объемы электронной торговли выросли. Одновременно с этим произошли и структурные изменения, потребители сменили свои приоритеты. Целью исследования стало изучение роли электронной коммерции в Китае в период пандемических ограничений, а также анализ статистических и структурных изменений электронной торговли в период эпидемии. Проведен количественный и качественный анализ, определены перспективы электронной торговли в Китае. Также использовались методы статистического и сравнительного анализа. Материалом послужили данные Национального бюро статистики Китая и других отрытых источников. Для определения перспектив электронной торговли построена модель с аддитивной компонентой. Проведена десезонализация данных, рассчитаны несколько вариантов тренда и подобран наиболее подходящий, который лучшим образом аппроксимирует данные о продажах. Анализ показал рост электронной коммерции в период пандемии в Китае, но не такой высокий как ожидался. Отмечается, что и до пандемии электронная коммерция росла довольно быстрыми темпами, а пандемия лишь немного ускорила ее рост. В период пандемии на новые формы продаж вынуждены были перейти и те компании, которые раньше не использовали интернет. Также эпидемия побудила людей попробовать множество новых продуктов и услуг, а затем и развить новые потребительские привычки, что в долгосрочной перспективе продолжит рост электронной торговли.
\end{abstract}

Ключевые слова: электронная коммерция, розничная торговля, COVID-19, ограничения пандемии, Китай

Благодарности. Статья подготовлена при поддержке Программы стратегического академического лидерства РУДН.

История статьи: поступила в редакцию 18 июня 2021 г.; проверена 1 июля 2021 г.; принята к публикации 15 августа 2021 г.

Для цитирования: Revinova S.Yu., Ivashchenko E.A. E-commerce in China amid COVID-19 pandemic restrictions // Вестник Российского университета дружбы народов. Серия: Экономика. 2021. Т. 29. № 4. С. 699-715. http://dx.doi.org/10.22363/2313-2329-2021-29-4-699-715

\section{Introduction}

Over the past few years, e-commerce has become an integral part of the global retail system. E-commerce is based on e-commerce in physical goods and services. As Internet access and distribution grows rapidly worldwide, the number of online shoppers continues to grow every year. In 2020, more than two billion people purchased goods or services online, and during the same year, Internet retail sales 
worldwide exceeded $\$ 4.2$ trillion. ${ }^{1}$ E-commerce statistics state that $40 \%$ of internet users worldwide purchase products or goods online using desktop computers, mobile devices, tablets, or other networked devices. It is over 1 billion online shoppers that are projected to grow steadily.

The top five leaders in retail e-commerce (B2C) in 2019 are as follows (Table 1): China is in first place with almost three times the $\mathrm{B} 2 \mathrm{C}$ e-commerce than in the UK, Japan and Germany combined. The United States is in second place, lagging China by $\$ 130$ billion.

Table 1

Rating of countries by the volume of B2C retail e-commerce in 2019 , $\$$ billion

\begin{tabular}{ccc}
\hline Place & Countries & B2C e-commerce volume \\
\hline 1 & China & 738 \\
2 & USA & 542 \\
3 & Japan & 89 \\
4 & United Kingdom & 79 \\
5 & Germany & 74 \\
\hline
\end{tabular}

Source: compiled by the authors based on the National Bureau of Statistics of China. Retrieved February 15,2021 , from https://data.stats.gov.cn/

E-commerce has great potential, which, however, can be better realized by solving existing problems. There are issues such as regulatory gaps, security issues, and cybercrime, consumer distrust, etc. The COVID-19 pandemic has given a new impetus to the growth of e-commerce, especially in trade, education, medicine, etc. During a pandemic, all non-contact areas of human activity received development due to their specificity, which was the best fit for existence under conditions of epidemiological restrictions. The global epidemic is still spreading, and its impact is still ongoing, but some conclusions can already be drawn.

\section{Research objective and methodology}

The purpose of this study is to determine what role e-commerce has played in the context of pandemic restrictions in China and its prospects, to analyze how the attitude of the population towards e-commerce has changed and what structural changes have occurred. The study was based on statistics from the National Bureau of Statistics of China and other open sources. The authors used methods of comparison, statistical and logical analysis. We built a model with an additive component. The data was deseasonalized, several trend variants were calculated, and the most suitable trend was selected that best approximates the sales data. In formulating conclusions, a generalization method is used.

\section{Theoretical background}

The growth of e-commerce is observed in all countries without exception, but it is growing especially rapidly in developing countries. The COVID-19 pandemic is having a significant impact on the development of e-commerce. Nowhere

${ }^{1}$ Statista. (2021). E-commerce worldwide. Retrieved September 15, 2021, from https://www.statista.com/topics/871/online-shopping/ 
else has there been unprecedented and unexpected growth like in the e-commerce sector that thrives on the COVID-19 crisis. $^{2}$ International trade trends forecast promising growth in global e-commerce sales (Dumanska et al., 2021). Consumers have begun to favor e-commerce, the fastest and most practical way to meet their needs amid the epidemic. E-commerce is a method that eliminates physical interactions other than receiving a shipment. It's important both for health but also for practicality, saving time and energy (Güven, 2020).

The epidemic has prompted people to try many new products and services and develop new consumption habits and concepts. It led to the creation of new consumer groups and new product requirements. Thus, it looks like a manifestation of people's willingness to pay for functionality and comfort in everyday and family life (Mazaheri, 2020). Buying behaviors are highly responsive to the epidemic extension (Yuan et al., 2021). Customers can buy the items they need to support this situation while they rethink and delay buying the items they need (Agus et al., 2021).

The popularity of e-commerce has increased by $17 \%$ since the outbreak of the COVID-19 pandemic and is expected to grow further. Sectors such as electronics, fashion and accessories, healthcare, pharmaceuticals, and fast-moving consumer goods performed exceptionally well with average sales growth of $133 \%$ (Sharma, 2020). E-commerce in food and agricultural products is experiencing significant growth. The additional confirmed case of COVID-19 increased sales by $5.7 \%$ and the number of customers by $4.9 \%$. Demand for grains, fresh fruits and vegetables, and frozen foods increased the most, benefiting small farms. The variety of products sold on the e-commerce platform has also increased during the pandemic, suggesting that the concentration of sales on niche products may increase as more consumers are attracted to online platforms (Chang, Meyerhoefer, 2021).

Trends established during this crisis could remain stable in the future, with severe repercussions for brick-and-mortar stores due to the rapid growth of e-commerce. The COVID-19 pandemic presents excellent opportunities to increase the availability of e-retailing. Still, a lack of professionalism could prevent traditional local retailers from retaining market share in the expanded online marketplace. It could be the final blow for local convenience stores if, as predicted, the percentage of online shopping in total retail spending remains high after the pandemic (Beckers et al., 2021).

Soon, consumers who are accustomed to the e-services, will inevitably have higher and higher requirements for it. E-commerce companies are encouraged to maintain and even improve the system's quality and the information's quality, as less attractive, less relevant and challenging to understand information leads to low-quality details, which in turn can reduce the level of use and customer satisfaction (Dirgantari et al., 2020; Bhatti et al., 2020). Businesses can stimulate buying behavior by conducting a clever marketing campaign and ensuring the transparency of their activities on the Internet (Koch et al., 2020). Companies need to be able to provide and create a positive experience for their customers (Palomino

${ }^{2}$ UNCTAD. (2021). How COVID-19 triggered the digital and e-commerce turning point. Retrieved September 15, 2021, from https://unctad.org/news/how-covid-19-triggered-digital-ande-commerce-turning-point 
et al., 2020; Parlakkiliç et al., 2020). While some shoppers may return to their old habits after the pandemic, many who have found value and satisfaction in their online experiences will continue to use e-commerce. During the pandemic, services and goods provided by places of business on the Internet served a very large number of customers. Only 1\% are dissatisfied (Veeragandham et al., 2020). In the long term, this will be a tipping point for digital changes in the ecosystem (Veeragandham et al., 2020).

Over the past years, China has been the leader in e-commerce turnover globally (Revinova, 2019). In addition, China was the first to face the COVID-19 epidemic. The peak of the outbreak in China fell in February 2020. Since the end of March, the economy has been actively recovering. According to preliminary calculations, the gross domestic product in the first half of 2020 was 45.661 billion yuan, down 1.6\% compared to the same period in 2019 at comparable prices. But if you look at the dynamics quarterly, then instead of the fall in the first quarter by $6.8 \%$ compared to the same period last year, GDP has already begun to show an increase of $3.2 \%$ in the second quarter. By the beginning of the second quarter, in April 2021, the total retail sales of consumer goods amounted to 3.535 .3 billion yuan, an increase of $17.7 \%$ over the same period in 2020 and increased by an average of $4.3 \%$ for the last two years. ${ }^{3}$

In the offline economy, primary consumption of food and necessities recovered, and then unnecessary consumption began to recover. The growth rate of real estate sales in the third quarter reached $20 \%$, the growth rate of car sales also approached $10 \%$. The recovery of the real estate and automobile markets stimulated the average demand for fuel extraction, and the industrial economic recovery accelerated in the fourth quarter. ${ }^{4}$

Experts said offline consumption was blocked in 2020 due to the impact of the new coronary pneumonia epidemic. But, at the same time, online consumption has reversed the trend, effectively promoting consumption replenishment, unlocking market potential, and opening up new ideas for economic recovery and development. China's market-led e-commerce platforms played a role, although the entire logistics system was vulnerable to the epidemic. In the hardest hit areas, especially in gated and isolated communities, the local e-commerce model has been the mainstream model (Guo et al., 2020). In the future, it is necessary to seize the opportunity to develop new online consumption, continue to promote the vigorous development of online consumption and achieve deep integration between online and offline.

Wang Jinbin, executive deputy secretary of the economics faculty at the People's University of China and a researcher at the National Institute of Development and Strategy, says the buying habits developed by consumers during the epidemic will continue to boost the consumer market and stabilize consumption. At the same time, it can also encourage offline companies to remain viable. ${ }^{5}$

${ }^{3} \mathrm{Li}, \mathrm{M}$. (2021). The country's economy continued to recover steadily in April. Retrieved December 5, 2020, from http://www.gov.cn/xinwen/2021-05/17/content_5607410.htm

${ }^{4}$ Epidemic Prevention Plan by Central People's Government of the People's Republic of China. Retrieved September 10, 2021, from http://www.gov.cn/xinwen/2020-07/16/content_5527279.htm

${ }^{5}$ Economic Daily. Retrieved December 5, 2020, from http://www.gov.cn/xinwen/202007/22/content_5528864.htm 
The purchasing habits developed by consumers during the epidemic will continue and will continue to boost the consumer market and stabilize consumption. The Chinese authorities say that in the future, their goals are to use to develop new online consumption, leveraging the vigorous development of online consumption, and achieve deep integration between online and offline sales.

\section{Results and discussion}

\section{China e-commerce statistics during the pandemic}

In recent years, China has been the fastest growing e-commerce market and the undisputed leader in the retail sector. However, the severe restrictions imposed in connection with the declared pandemic have seriously impacted the volume of all China's trade. In the first half of 2020, just in the most severe restrictions on mobility, retail sales of consumer goods in e-commerce declined, but not much compared to traditional trade (Table 2). And in the next six months of 2020, growth relative to previous periods is already at a high pace, and in all types of trade.

The fluctuations in the total volume of all retail sales of physical goods during the pandemic coincide with the changes in e-commerce (Figure 1); with an increase in the share of retail trade through the Internet, the total volume of all retail also increased.

Table 2

Total retail sales of consumer goods, billion yuan

\begin{tabular}{cccc}
\hline Period & Via the Internet & In the traditional way & Total growth \\
\hline 1st half of the year 2019 & 3816.49 & 15704.48 & 19520.97 \\
2d half of the year 2019 & 4707.46 & 16936.47 & 21643.93 \\
1st half of the year 2020 & 4348.07 & 12877.55 & 17225.62 \\
2d half of the year 2020 & 5410.96 & 16561.48 & 21972.44 \\
\hline
\end{tabular}

Source: compiled by the authors based on the National Bureau of Statistics of China. Retrieved February 15, 2021, from https://data.stats.gov.cn/

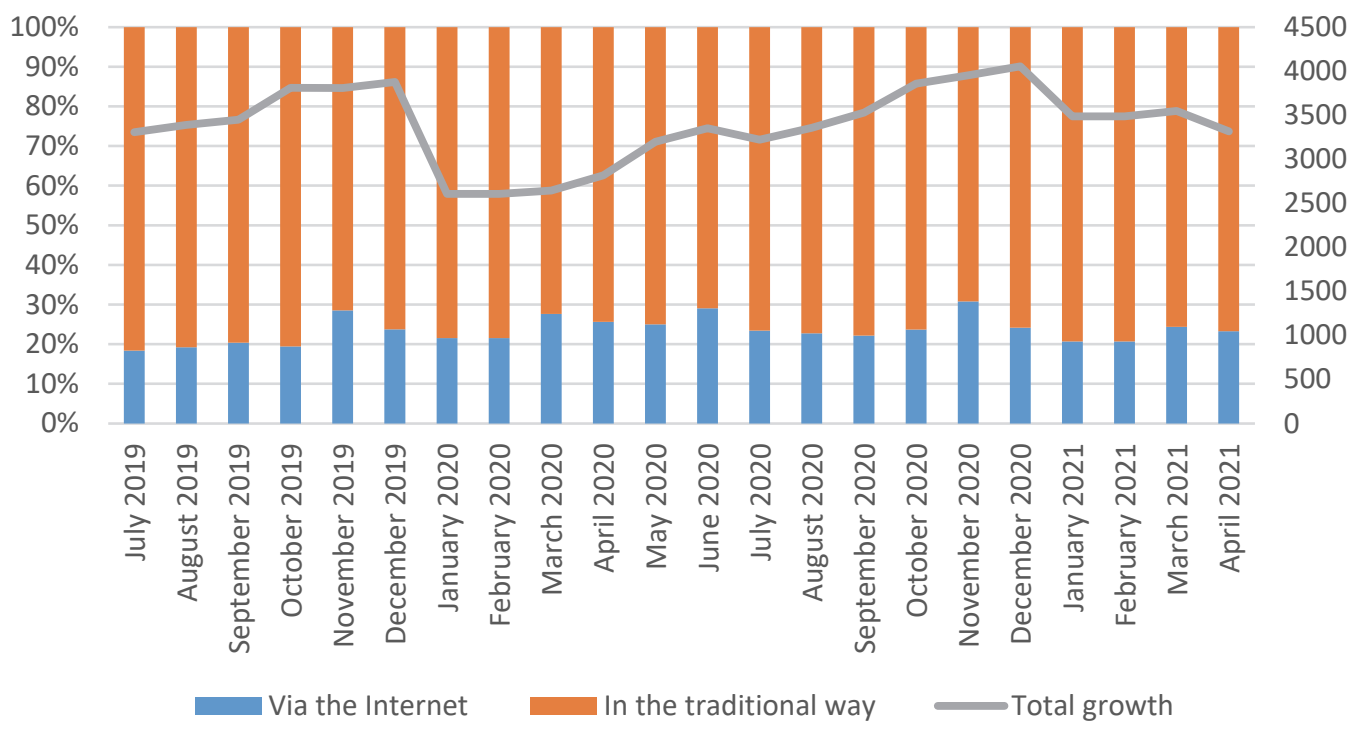

Figure 1. Dynamics of the total retail sales of consumer goods by months

Source: compiled by the authors based on the National Bureau of Statistics of China. Retrieved February 15, 2021, from https://data.stats.gov.cn/ 
At the same time, the share of e-commerce in retail sales of consumer goods has grown by several percentage points in such a short time. As we can see, in April 2021, it is about 25\%. By this time, most of the restrictions in China had already been lifted and, but the growth in the share of electronic commerce continued.

In general, electronic, and traditional trade in consumer goods move approximately along the same trajectory, repeating the main large-scale fluctuations of each other (Figure 2). It means that their ups and downs are primarily in line with the general economic environment. But, if we take a closer look at the prominent peaks in the retail sales of consumer goods over the Internet, we will notice that they always coincide with the decreases in the purchase activity in the traditional way (for example, November 2019, March, June, November 2020). That is, there is a kind of substitution of one for the other. At the same time, it is important to note that during this entire transition period we are considering, there was ultimately no large decline in sales volumes in the traditional form, although there were undoubtedly ups and downs. Over the entire period, the volume of e-commerce in consumer goods increased, but not too much, from 606.84 billion yuan in July 2019 to 770.62 billion yuan in April 2021. Although it is not so small in percentage terms, it grew by $27 \%$ over these months, while in the traditional component there was a slight decline. In addition, of course, let's say that in the traditional trade in physical goods, there was a protracted and deep recession in the first months of 2020, the reason for which lies on the surface.

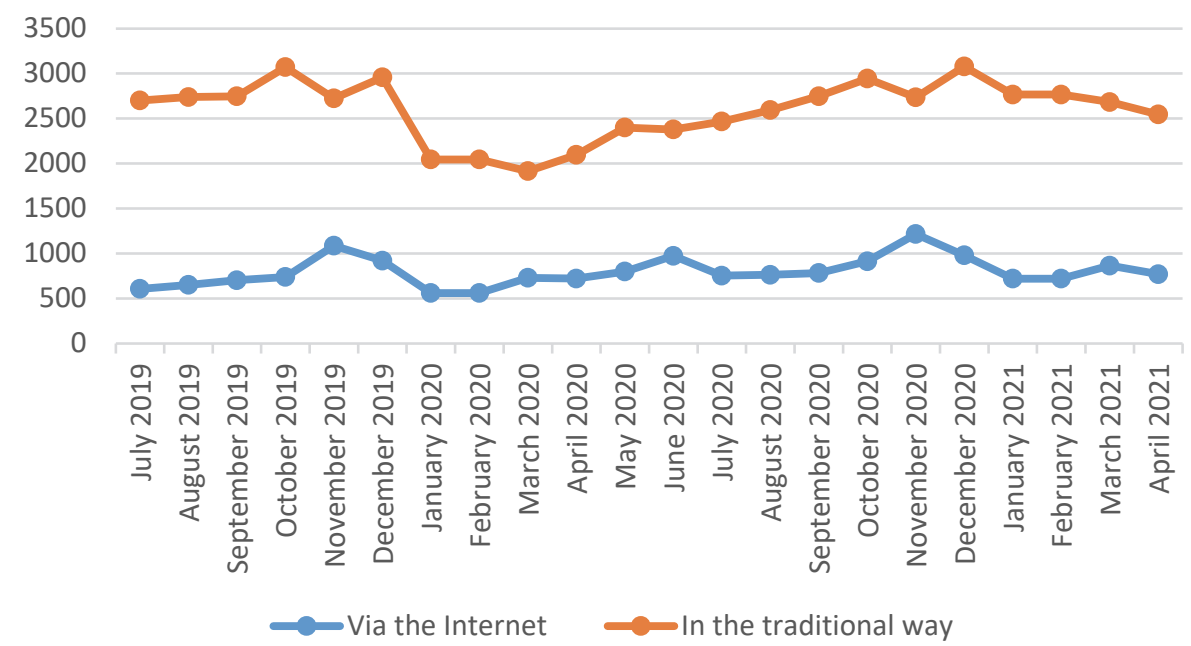

Figure 2. Dynamics of total retail sales of consumer goods in billion yuan

Source: compiled by the authors based on the National Bureau of Statistics of China. Retrieved February 15,2021 , from https://data.stats.gov.cn/

At the beginning of 2020, with the onset of the epidemic, there was a drop in retail e-commerce, but then it rapidly increased in volume (Figure 3 ).

By the end of 2020, the share of online commerce in China was 24.9 (Figure 4). At the same time, it should be noted that the annual growth was observed over the past years, but in 2020 it reached $4.3 \%$ (Figure 5). 


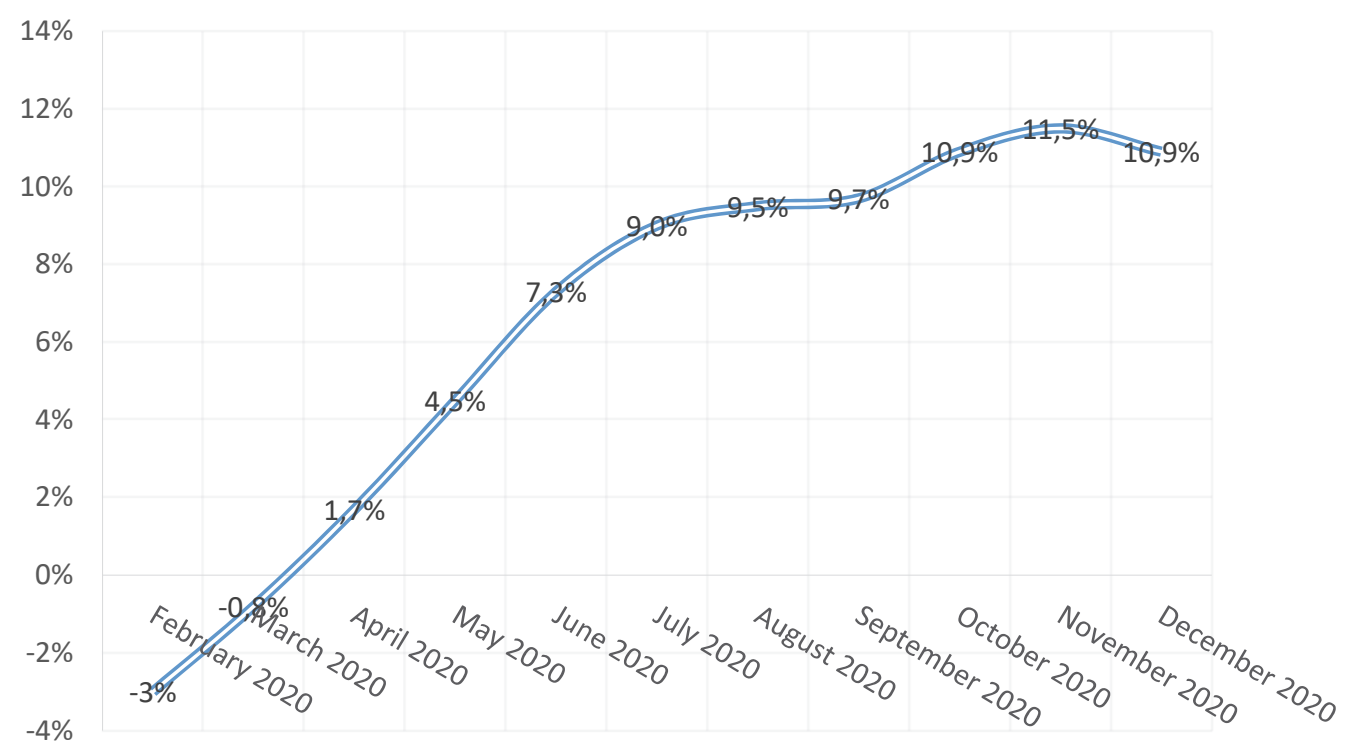

Figure 3. Growth in retail e-commerce as a percentage of data at the beginning of the year

Source: compiled by the authors based on the National Bureau of Statistics of China. Retrieved February 15, 2021, from https://data.stats.gov.cn/

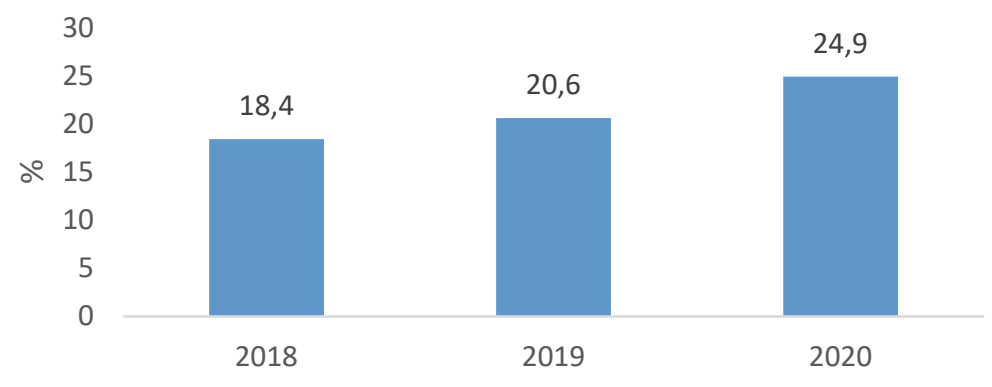

Figure 4. Share of online trade in total retail trade

Source: compiled by the authors based on the National Bureau of Statistics of China. Retrieved February 15,2021 , from https://data.stats.gov.cn/

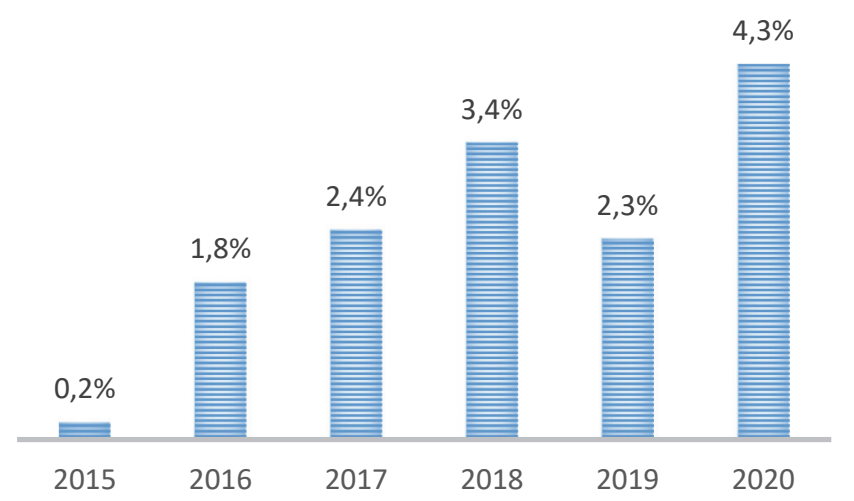

Figure 5. Growth in the share of e-commerce in the total retail trade in China

Source: compiled by the authors based on the National Bureau of Statistics of China and Statista. Retrieved February 26, 2021, from https://data.stats.gov.cn/; https://www.statista.com/ 
Throughout 2020, we have not seen any negative growth. On the contrary, in absolute terms, China's e-commerce retail sector showed the highest growth rates in June and the last quarter of 2020 (Table 3). Moreover, in the second half of the year, when already lifted most of the restrictions, the volume of retail e-commerce did not decline but began to increase at a faster pace. This pattern can, perhaps, be explained by the improvement in the economic situation in the country because everything in China at that time had already returned to its usual course. Thus, fears about the future, the presence or absence of a job, a lost permanent income are in the past.

Table 3

Dynamics of online retail trade volumes in 2020 by months

\begin{tabular}{ccc}
\hline Period & Accumulated amount, trillion yuan & Monthly growth, trillion yuan \\
\hline February 2020 & 1.37 & 0.68 \\
March 2020 & 2.22 & 0.85 \\
April 2020 & 3.07 & 0.85 \\
May 2020 & 4.02 & 0.95 \\
June 2020 & 5.15 & 1.13 \\
July 2020 & 6.08 & 0.93 \\
August 2020 & 7.03 & 0.95 \\
September 2020 & 8.01 & 0.97 \\
October 2020 & 9.22 & 1.21 \\
November 2020 & 10.54 & 1.32 \\
December 2020 & 11.76 & 1.22 \\
\hline
\end{tabular}

Source: compiled by the authors based on the National Bureau of Statistics of China. Retrieved February 15,2021 , from https://data.stats.gov.cn/

In the last quarter of 2020, this growth is associated with the boom in online purchases of the "Double Eleventh" and "Double Twelfth" numbers (11.11 and 12.12). In China, sales are taking place on all online platforms on these dates to stimulate the vitality of the consumer market. As a result, in the fourth quarter, the volume of e-commerce transactions in personal goods was 3.1 trillion yuan, an increase of $14.3 \%$. The six largest online shopping platforms at Double Eleven have broken sales records. New retail, realized by integrating commercial resources such as supermarkets and shops in nearby communities into the Internet, has maintained strong momentum and the top ten new retail platforms in terms of transaction scale. Geographically, e-commerce transactions grew at a rapid pace across all regions of China in the fourth quarter.

Even though the pandemic is not over yet and lockdowns are periodically announced in certain areas, we can already say that e-commerce can become the engine of economic recovery in the short term. E-commerce is one of the core points of the digital economy, which is a driver of economic growth nowadays (Balashova et al., 2018). Also, the data obtained allows us to determine some trends in the development of e-commerce and consumer behavior.

\section{The main trends in e-commerce in China, formed during the pandemic}

In 2020, the volume of e-commerce transactions for commodities in China totaled 1.15 trillion yuan, an increase of $10.9 \%$. Most of these products are sold and bought by manufacturing companies, which also had to gradually develop 
online supplies so that the organizations could continue to function. The volume of transactions in shares was 20.60 billion yuan, an increase of $29.6 \%$. This phenomenon is directly related to the fact that having started the use of transactions with means of payment over the network, the population has become more literate in various banking and investment services, which has increased confidence in the sale and purchase of securities via the Internet (Reshetnikova, 2020). The volume of art deals amounted to 8.229 billion yuan, showing a $49.2 \%$ decline from 2019 , indicating a reorientation of consumption. Art and luxury are becoming more inaccessible due to the economic hardships that COVID-19 has brought with it in one way or another. In addition, this is just one of those types of goods, the demand for which can be postponed until the restrictions are lifted so that people can choose such expensive things through direct contact with the seller and the work of art itself.

The growth of e-commerce is observed in the private sector and B2B (Business-to-Business). When manufacturing activities resumed growth, Internet supplies continued, including supplies from the production and production of raw materials. In the fourth quarter, the volume of e-commerce transactions per product unit was 5.39 trillion yuan, up 9.2\% over the same period last year. As for the procurement of raw materials, the volumes of transactions with construction materials, oil and gas, coal, and agricultural products multiplied: 24.3, $14.5,38.7$, and $232.5 \%$ respectively. ${ }^{6}$ The increase in the number of transactions with goods against the background of the growth of industrial production and construction in the China actively supported and stimulated by government.

Due to the increase in demand for them around the world during the pandemic, medical goods and electronics were actively exported. The volume of transactions in the supply chain for cars and televisions increased by 16.9 and $36.3 \%$ respectively. Sales of medical products multiplied, with a growth rate of 54.8\%. The growth rates of petroleum products and cement sales amounted to 64.5 and $27.5 \%$, respectively, which is still associated with the inflow of investments in the industrial and construction industries. Finally, the number of transactions for the purchase of alcoholic beverages grew at the highest rates $-223.5 \%$. It does not mean that alcohol has become more often consumed by the Chinese population. On the contrary, in absolute terms, its sales declined. According to the global trend, there was an increase in online transactions and a shift in network demand.

The phenomenal growth in online sales in the agricultural sector is worth mentioning separately. There are many different programs to combat poverty in families, in villages, and even in entire districts in China. Often, the population in these areas is engaged in agriculture. COVID-19 has forced agricultural producers to take the first steps of e-commerce, and the Chinese authorities have decided to make the most of digital platforms for another advance in solving poverty. The likes of the giants Alibaba, Pinduoduo introduced gift, discount coupons for agricultural products when buying online. During the big harvest festival that lasted all September, many new brands of agricultural products were created on e-commerce platforms. In this way, the state seeks to raise the popularity and value of the Chinese rural brand.

${ }^{6}$ China e-commerce transaction volume in 2020. Retrieved February 15, 2021, from http://www.zgxxb.com.cn/xwzx/202102030007.shtm 
The coronavirus pandemic has affected the service sector as well. In 2020, the volume of e-commerce services transactions amounted to 8.08 trillion yuan, down $6.5 \%$ from the previous year. In the first quarter, at the beginning of the pandemic, a drop of $20.0 \%$ was recorded, in the second - by $11.8 \%$, in the third quarter there was again a decrease by $5.4 \%$, and in the fourth quarter - already an increase of $6,6 \%$. In the fourth quarter, e-commerce service transaction volume was 2.60 trillion yuan. Personal transactions accounted for 1.38 trillion yuan, an increase of $8.0 \%$, and organizational unit transactions, 1.22 trillion yuan, an increase of $5.0 \%$.

Travel services were the worst affected by the pandemic. The recovery of long-distance travel using railways and civil aviation has been slow, while shortdistance journey, such as road transport, has been faster. A similar phenomenon is easy to explain: China's borders with other countries are closed, and now, between the provinces after entering from the pandemic, communication and movement also resumed gradually, so road transport, focused on short distances, recovered, respectively, faster. As a result, the number of travel internet platforms has decreased. Railroad e-commerce transactions were down $25.8 \%$ year-over-year in the fourth quarter, but the decline was down 7.1 percentage points from the third quarter. Transaction volume across the top five e-commerce travel platforms fell $29.6 \%$, but the rate of decrease slowed by $19 \%$. The number of orders for transport services online amounted to 2.818 billion, an increase of $8.3 \%$, since domestically, between regions by this time and travel opportunities have already recovered. The volume of transactions on the civil aviation ticketing platform declined by $55.7 \%$ due to the fall in ticket prices, precisely because airlines account for the significant share of cross-border passenger and cargo transportation flights.

In the fourth quarter, the transaction volume of 310 consumer services sites surveyed across the country increased 55.5\% year-on-year, up 11.5\% from the third quarter. Influenced by the epidemic, online transactions continued to grow for services such as gas, water, and electricity bills, home reservations, and food delivery, which are closely linked to the daily life of the population. The transaction volume of the four leading e-commerce platforms for accommodation and catering increased $13.0 \%$ year-on-year, up $8.5 \%$ quarter-on-quarter. ${ }^{7}$ Initially, this growth was caused by the limited mobility of the population, but during the pandemic, such services became familiar and gained popularity among the people. It became clear that in subsequent periods they could continue to simplify everyday processes. The increase in volumes compared to the 3 rd quarter indicates the preservation of the emerging trend, the continuation of mastering the possibilities of making service payments via the Internet.

In the context of the COVID-19 pandemic, universities, colleges and schools around the world have been forced to study remotely to reduce the spread of the rapidly transmitting virus. Many new online platforms have emerged (Revinova, Lazanyuk, 2020). In Chine in the fourth quarter of 2020, the transaction volume of online learning platforms increased by $153.5 \%$ compared to the same period last year. Sixteen e-education platforms were recorded with an average

${ }^{7}$ China e-commerce transaction volume in 2020. Retrieved February 15, 2021, from http://www.zgxxb.com.cn/xwzx/202102030007.shtm 
monthly transaction volume of more than 100 million yuan, a 2-fold increase compared to the period before COVID-19. Online medical platform transaction volume increased by $87.6 \%$; the number of online medical consultations reached 92.72 million, an increase of $16.7 \%$; the number of online recipes was 4.036 million, an increase of $268.5 \%{ }^{8}$ Of course, in the period before the pandemic in Chine, as in many other countries, the population rarely received education or medical services online, especially since both of these services have several traditional features important for the Chinese. For example, all traditional Chinese medicine. Previously, it was impossible to imagine her without personal contact with the patient. But COVID-19 here, too, has made its adjustments and gave impetus. However, we see the data for the 4th quarter, showing us, of course, not as high indicators as during the period of active pandemic restrictions but did not come to naught after their abolition. The epidemic, one might say, practically gave birth to these industries as such, since before it, they were poorly represented and were not in such demand. Many new formats of doing business and trade have appeared (Nanda et al., 2021). The streaming sales sector, that is, live sales, somewhat reminiscent of the pre-existing shops on the couch, has skyrocketed. In February 2020, Taobao added over 1 million sellers, and the number of new sellers offering their products live on Taobao increased by $719 \%$ monthly. For example, in the book industry, retail growth through such activities as digital reading was about $938 \% .{ }^{9}$ Even very financially demanding goods, such as houses and cars, got the opportunity to market in this way. In addition, live broadcasting provides more opportunities for brand communication with the audience, attracting its attention.

The rapid growth of online sales contributed to the repeated renewal of retail schemes and forms and the structure of consumption. One of the main components of the realities of online trading is the instant delivery of food and groceries. In the short term, in the first half of 2020, there was a boom in the pharmaceutical industry, masks became the sales leader. In addition, the focus of consumption has shifted towards home comfort and personal care, which is more than logical. Food consumption, clothing, and consumer goods increased by $30.6,5.8$, and $16.2 \%$. As we can see, online retail sales have increased due to the transition to online shopping for food and general consumer goods. ${ }^{10}$

\section{Prospects for e-commerce after the restrictions are lifted}

For e-commerce companies, the critical question is what to expect in the near future, will the new consumer habits remain the same after the restrictions are lifted, when the two key factors "people can't go out" and "people have to cook at home" will disappear?

According to the results of a survey by the Central People's Government of China, $80 \%$ of people believed that they would not have to restore and reimburse

\footnotetext{
${ }^{8}$ China e-commerce transaction volume in 2020. Retrieved February 15, 2021, from http://www.zgxxb.com.cn/xwzX/202102030007.shtm

${ }^{9}$ China Electronic Commerce Report 2019. Retrieved November 28, 2020, from http://www.199it.com/archives/1076562.html

${ }^{10}$ State Bureau of Statistics of China Report. Retrieved March 21, 2021, from http://www.stats.gov.cn/tjsj/zxfb/202101/t20210118_1812428.html
} 
the consumption of some goods. It means there is a high probability that there will not be a sharp increase in compensatory consumption after the epidemic. In the second quarter, when many restrictions were lifted in the PRC, the average use time of applications decreased by only $2.5 \%$ compared to the period when the entire population existed in a remote format. At the same time, this value was still 9\% higher than before the Chinese New Year. In other words, with the introduction of full-time office workers, online life has remained much more active. The next step for companies that have successfully attracted new platforms during the epidemic is to achieve long-term retention in a highly competitive environment. As consumers move from forced to consistent and active choices, they become more finicky. Standing out in the struggle for their preference is not easy. However, it is an efficient competition that tests the entire online service chain, nearby production chains, and chain stores.

According to forecasts of some experts, the purchasing habits developed by consumers during the epidemic will continue and give impetus to the consumer market and grow production - for example, online delivery of goods. Thanks to providing the customer with the right product immediately when the need arises, the information asymmetry between supply and demand is reduced, and the true consumption potential is revealed. At the same time, it will help offline companies remain viable. After all, some manufacturers also optimize production based on consumption data provided by the current e-commerce platform, create individualized and specialized products, new business models, and form an influential circle of mutual promotion of supply and demand. ${ }^{11}$ Shopping centers, on the other hand, are experiencing a churn of shoppers. In the short term, businesses are trying more and more online to ensure sustainability. In March 2020, even IKEA, which focuses on offline immersive experiences, also opened a flagship store on Tmall, offering around 3,800 items. But one way or another, it is difficult to recover the lost sales.

So far, at this point, it cannot be said that there has been some phenomenal growth in e-commerce in 2020, especially in the context of, so, relatively high growth rates of e-commerce in China in recent years. But, on the other hand, the fact that after the restrictions were lifted, the volume of purchases on the Internet continued to grow, and even faster than during the pandemic, speaks of the sustainability of this trend.

Based on the quarterly statistics on retail sales of consumer goods over the Internet provided by the National Bureau of Statistics of China, we built a model and made a forecast for the development of e-commerce in China. The retail sales volume of consumer goods via the Internet in Chine has a pronounced seasonality (annual surges in activity in the last quarter, for example). Therefore, to build a forecast, we cleared the data from the influence of seasonal fluctuations (Figure 6).

We make a forecast based on an additive model like $F=T+S+E$, where $F$ is the predicted value, $T$ is the trend value, $S$ is the seasonal component, $E$ is the random component or forecast error. The model makes it possible to forecast

${ }^{11}$ Central People's Government of the People's Republic of China. (2020). Offline and online consumption during a pandemic in the first quarter. Retrieved November 26, 2020, from http://www.gov.cn/xinwen/2020-07/22/content_5528864.htm 
data that have a cyclical or seasonal nature. We calculate the seasonal component and go through the data deseasonalization procedure. The most appropriate function that best describes the trajectory of the sales data is linear, with a determination coefficient of $49.5 \%$. The linear function has the following data:

$$
\begin{gathered}
y=89.19 x+1590.7 \\
R^{2}=0.4949
\end{gathered}
$$

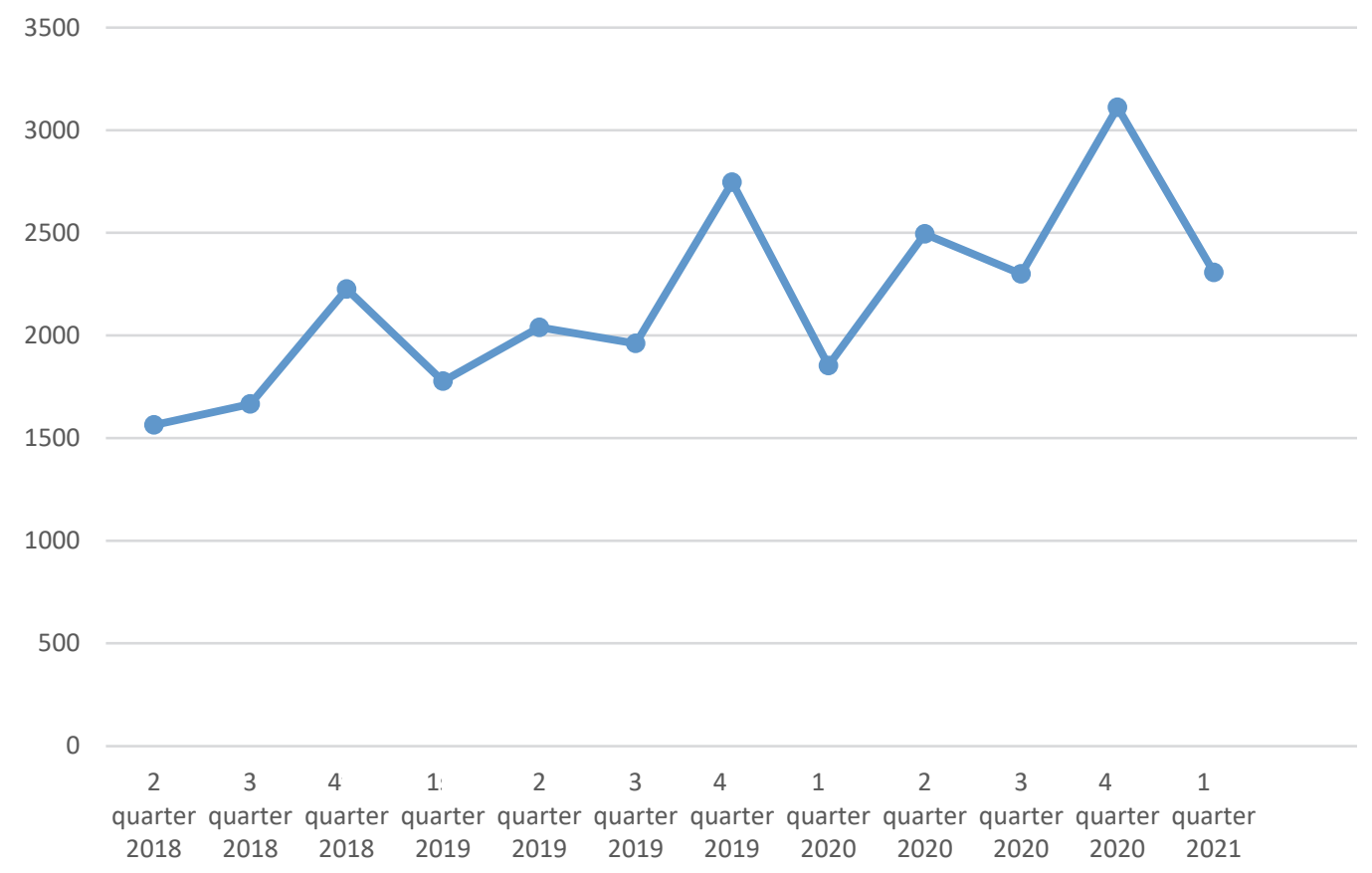

Figure 6. Dynamics of the actual volume of retail electronic trade in physical goods

Source: compiled by the authors based on the National Bureau of Statistics of China. Retrieved February 15,2021 , from https://data.stats.gov.cn/

To assess the accuracy of the forecast, we will calculate the standard errors (Table 4).

To assess the forecast accuracy, we calculated the following indicators. The obtained value of the mean absolute deviation (MAD) indicates that, on average, the forecast may deviate by 76.99 billion yuan up or down. At the same time, judging by the average relative approximation error (MAPE), equal to $3.92 \%$, the additive model has a high accuracy, conventionally accepted as the boundary of the value of this indicator, is the mark of $10 \%$. The average percentage error (MPE) has a negative value $(-0.284 \%)$, which suggests that the forecast may be slightly overestimated. So, the estimated values of the forecast, retail e-commerce in physical goods in the PRC will equal in the 2nd and 3rd quarters of 2021, equal to 2792.56 billion yuan and 2656.84 billion yuan, respectively (Figure 7). 
Estimation of forecast accuracy

\begin{tabular}{cccccc}
\hline No & $\boldsymbol{t}$ & $\begin{array}{c}\text { Actual sales } \\
\text { volume } \boldsymbol{Q}\end{array}$ & $\begin{array}{c}\text { Seasonal } \\
\text { component } \boldsymbol{S}\end{array}$ & $\begin{array}{c}\text { Trend } \\
\text { component } \boldsymbol{T}\end{array}$ & $\begin{array}{c}\text { Forecasted } \\
\text { value } \boldsymbol{F}\end{array}$ \\
\hline 1 & 2 quarter 2018 & 1563.83 & 42.39 & 1679.89 & 1722.28 \\
2 & 3 quarter 2018 & 1666.11 & -182.52 & 1769.08 & 1586.56 \\
3 & 4 quarter 2018 & 2226.05 & 454.33 & 1858.27 & 2312.60 \\
4 & 1 quarter 2019 & 1777.20 & -314.20 & 1947.46 & 1633.26 \\
5 & 2 quarter 2019 & 2039.29 & 42.39 & 2036.65 & 2079.04 \\
6 & 3 quarter 2019 & 1961.20 & -182.52 & 2125.84 & 1943.32 \\
7 & 4 quarter 2019 & 2746.26 & 454.33 & 2215.03 & 2669.36 \\
8 & 1 quarter 2020 & 1853.57 & -314.20 & 2304.22 & 1990.02 \\
9 & 2 quarter 2020 & 2494.50 & 42.39 & 2393.41 & 2435.80 \\
10 & 3 quarter 2020 & 2299.62 & -182.52 & 2482.60 & 2300.08 \\
11 & 4 quarter 2020 & 3111.34 & 454.33 & 2571.79 & 3026.12 \\
12 & 1 quarter 2021 & 2306.73 & -314.20 & 2660.98 & 2346.78 \\
13 & 2 quarter 2018 & 0.00 & 42.39 & 2750.17 & 2792.56 \\
14 & 3 quarter 2018 & & -182.52 & 2839.36 & 2656.84 \\
\hline
\end{tabular}

Source: calculated by the authors.

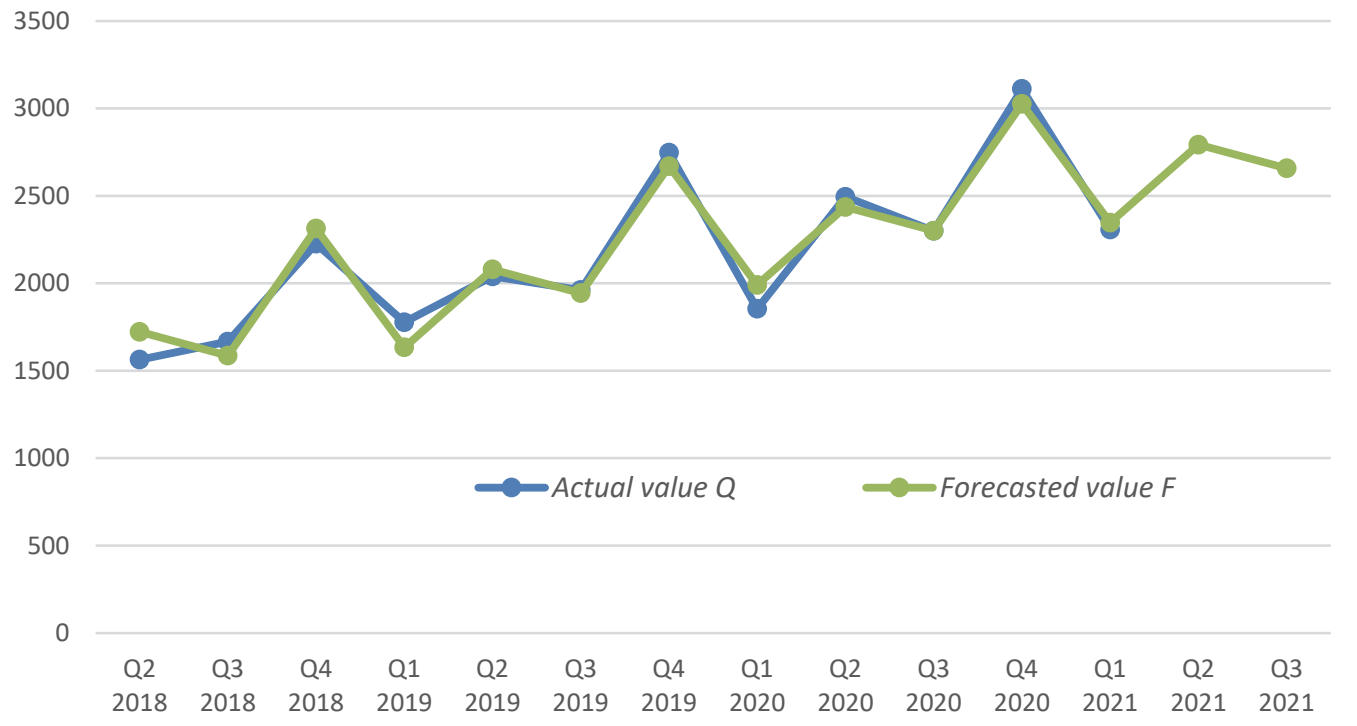

Figure 7. Linear model for forecasting the development of e-commerce in China

Suppose we hypothetically assume that this part of trade will continue to grow at the same rate, then, theoretically, in about 5 years in retail sales of goods. In that case, the electronic component will make up half of the total volume.

\section{Conclusion}

E-commerce is one of those activities for which the coronavirus epidemic gave an additional impetus to development, increased turnover and volumes, and not vice versa. While epidemiological restrictions have blocked offline consumption, online consumption has effectively fostered consumption replenishment, un- 
locking market potential and opening up new ideas for economic recovery and development. After emerging from the pandemic, e-retail has maintained its increased share and upward trend, but more smoothly than during the immediate period of restrictions. The Chinese authorities aim to establish integration between online and offline trade for complete economic development. The Chine government supports the active use of e-commerce platforms to develop problem sectors of the economy, social e-commerce, combat poverty, and raise agriculture.

We must say that in the context of pandemic restrictions, of course, the number of online buyers and sales through the Internet could not but increase. But it is also important to note that changes have taken place in quantitative terms and the qualitative component of e-commerce. Many new forms and methods of selling goods online, such as streaming sales, were organized during and after the pandemic. The focus of consumption, not only in the short term but also in the long term, has slightly shifted towards luxury goods. The epidemic has prompted people to try many new products and services and develop new consumption habits and concepts. In the long term, the epidemic's impact is much more multifaceted than just selling during the pandemic's aversion. The epidemic has accelerated the trend towards online transactions in society. The benefits of online shopping are attracting consumers while reducing the scale of sales in the real sector.

\section{References}

Agus, A.A., Yudoko, G., Mulyono, N., \& Imaniya, T. (2021). E-commerce performance, digital marketing capability and supply chain capability within e-commerce platform: Longitudinal study before and after COVID-19. International Journal of Technology, 12(2), 360. https://doi.org/10.14716/ijtech.v12i2.4122

Balashova, S., Lazanyuk, I., \& Matyushok, V. (2018). Growth scenarios for the Russian economy. In B.S. Sergi (Ed.), Exploring the Future of Russia's Economy and Markets: Towards Sustainable Economic Development (pp. 235-256). London, Emerald Publishing Limited. https://doi.org/10.1108/978-1-78769-397-520181013

Beckers, J., Weekx, S., Beutels, P., \& Verhetsel, A. (2021). COVID-19 and retail: The catalyst for e-commerce in Belgium? Journal of Retailing and Consumer Services, 62. https://doi.org/10.1016/j.jretconser.2021.102645

Bhatti, A., Akram, H., Basit, H.M., Khan, A.U., Mahwish, S., Naqvi, R., \& Bilal, M. (2020). E-commerce trends during COVID-19 Pandemic. International Journal of Future Generation Communication and Networking, 13(2), 1449-1452.

Chang, H.H., \& Meyerhoefer, C.D. (2021). COVID-19 and the demand for online food shopping services: Empirical evidence from Taiwan. American Journal of Agricultural Economics, 103(2), 448-465. https://doi.org/10.1111/ajae.12170

Dirgantari, P.D., Hidayat, Y.M., Mahphoth, M.H., \& Nugraheni, R. (2020). Level of use and satisfaction of e-commerce customers in COVID-19 pandemic period: An information system success model (ISSM) approach. Indonesian Journal of Science and Technology, 5(2). https://doi.org/10.17509/ijost.v5i2.24617

Dumanska, I., Hrytsyna, L., Kharun, O., \& Matviiets, O. (2021). E-commerce and m-commerce as global trends of international trade caused by the COVID-19 pandemic. WSEAS Transactions on Environment and Development, 17, 386-397. https://doi.org/10.37394/232015.2021.17.38

Guo, H., Liu, Y., Shi, X., \& Chen, K. Z. (2020). The role of e-commerce in the urban food system under COVID-19: Lessons from China. China Agricultural Economic Review, 13(2), 436-455. https://doi.org/10.1108/CAER-06-2020-0146 
Güven, H. (2020). Changes in e-commerce in the COVID-19 pandemic crisis process. Eurasian Journal of Researches in Social and Economics (EJRSE), 7(5), 000-000.

Koch, J., Frommeyer, B., \& Schewe, G. (2020). Online shopping motives during the COVID-19 pandemic - lessons from the crisis. Sustainability, 12(24). https://doi.org/10.3390/su122410247

Mazaheri, E. (Ed.). (2020). The impact of COVID-19 on e-commerce. London, Proud Pen. https://doi.org/10.51432/978-1-8381524-8-2

Nanda, A., Xu, Y., \& Zhang, F. (2021). How would the COVID-19 pandemic reshape retail real estate and high streets through acceleration of E-commerce and digitalization? Journal of Urban Management, 10(2), 110-124. https://doi.org/10.1016/j.jum.2021.04.001

Palomino Pita, A.F., Carolina, M.V., \& Oblitas Cruz, J.F. (2020). E-commerce and its importance in times of COVID-19 in Northern Peru. Revista Venezolana de Gerencia, 25(3), 253-266. https://doi.org/10.37960/rvg.v25i3.33367

Parlakkiliç, A., Üzmez, M., \& Mertoğlu, S. (2020). How does COVID-19 pandemic effect online shopping in e-commerce? Journal of Business in The Digital Age, 3(2), 117-122. https://doi.org/10.46238/jobda.823955

Reshetnikova, M. (2020). Venture capital market in China: A new approach to innovation management. Utopía y Praxis Latinoamericana: Revista Internacional de Filosofía Iberoamericana y Teoría Social, (5), 252-264.

Revinova, S. (2019). E-commerce in BRICS: Similarities and differences. International Journal of Economic Policy in Emerging Economies, 12(4), 377-390. https://doi.org/10.1504/IJEPEE.2019.104632

Revinova, S., \& Lazanyuk, I. (2021). E-learning trends and benefits: Russian realities. INTED2021 Proceedings (pp. 1295-1304). https://doi.org/10.21125/inted.2021.0302

Sharma, K. (2020). A surge in e-commerce market in India after COVID-19 pandemic. A Global Journal of Social Sciences, 3(December), 54-57.

Veeragandham, M., Patnaik, N., Tiruvaipati, R., \& Guruprasad, M. (2020). Consumer buying behaviour towards e-commerce during COVID-19. International Journal of Research in Engineering, Science and Management, 3(9), 78-82. https://doi.org/10.47607/ijresm.2020.292

Yuan, Y., Guan, M., Zhou, Z., Kim, S., Cha, M., Jin, D., \& Li, Y. (2021). Disruption in Chinese e-commerce during COVID-19. Frontiers in Computer Science, 3, 19. https://doi.org/10.3389/fcomp.2021.668711

\section{Сведения об авторах / Bio notes}

Ревинова Светлана Юрьевна, кандидат экономических наук, доцент кафедры экономико-математических отношений, Российский университет дружбы народов. ORCID: 00000002-2442-2393. E-mail: revinova-syu@rudn.ru

Иващенко Екатерина Александровна, бакалавр экономики, кафедра экономикоматематических отношений, Российский университет дружбы народов. E-mail: 1032182826@rudn.ru
Svetlana Yu. Revinova, Candidate of Economic Sciences, Associate Professor of the Department of Economic and Mathematical Relations, Peoples' Friendship University of Russia (RUDN University). ORCID: 0000-0002-2442-2393. E-mail: revinova-syu@rudn.ru

Ekaterina A. Ivashchenko, Bachelor of Economics, Department of Economic and Mathematical Relations, Peoples' Friendship University of Russia (RUDN University). E-mail: 1032182826@rudn.ru 